\title{
PENGUATAN NILAI KARAKTER GENERASI MUDA MENJADI MODAL WUJUDKAN KEUTUHAN BERBANGSA DAN BERNEGARA
}

\author{
Penulis \\ Nani Mediatati \\ Dosen Program Studiu PPKn \\ FKIP-UKSW Salatiga \\ Email: nanimediatati@gmail.com
}

\begin{abstract}
Abstrak
Penelitian ini bertujuan mendeskripsikan membangun karakter generasi muda yang beretika pancasila dalam kebhinnekaan. Jenis penelitian ini adalah penelitian kepustakaan (library Research). Metode pengumpulan data dilakukan dengan mengkaji buku-buku, hasil penelitian, makalah, skripsi, thesis, desertasi, artikel yang berkaiatn dengan materi yang diteliti. Teknik analisis data dilakukan secara kualitatif yaitu mengkroscekkan data-data terseleksi dari berbagai sumber baik yang on line maupun tidak. Selanjutnya dilakukan display data, dan penarikan kesimpulan. Hasil penelitian berdasarkan pengkajian berbagai sumber ditemukan bahwa ada 18 karakter yang wajib dimiliki generasi muda (Kemendikbud ) yaitu; Religius, Jujur, Toleransi, Disiplin, Kerja keras, Kreatif, Mandiri, Demokratis, Rasa Ingin Tahu, Semangat Kebangsaan, Cinta Tanah Air, Menghargai Prestasi, Bersahabat/Komunikatif, Cinta Damai, Gemar Membaca, Peduli Lingkungan, Peduli Sosial, Tanggung Jawab. Dari 18 nilai tersebut menurut Perpres Nomor 87 Tahun 2017 tentang Penguatan Pendidikan Karakter disebutkan, Penguatan Pendidikan Karakter yang selanjutnya disingkat PPK adalah gerakan pendidikan di bawah tanggung jawab satuan pendidikan untuk memperkuat karakter peserta didik melalui harmonisasi olah hati, olah rasa, olah pikir, dan olah raga. Menurut Penpres tersebut ada 5 nilai karakter yang sangat perlu dilakukan PPK dilaksanakan dengan menerapkan nilai-nilai Pancasila dalam pendidikan karakter terutama meliputi nilai-nilai religius, jujur, toleran, disiplin, bekerja keras, kreatif, mandiri, demokratis, rasa ingin tahu, semangat kebangsaan, cinta tanah air, menghargai prestasi, komunikatif, cinta damai, gemar membaca, peduli. Kelima nilai tersebut dilakukan penguatan melalui 3 lingkungan pendidikan yaitu keluarga, sekolah, dan masyarakat dengan strategi : pembiasaan, keteladanan, penghargaan dan hukuman yang bersifat edukatif. Kelima nilai karakter dilakukan penguatan karena banyak fenomena yang dilakukan generasi muda baik berupa sikap, perilaku dan perbuatan yang menyimpang dari lima nilai karakter tersebut. Jika tidak dilakukan penguatan dapat mengancam kehidupan berbangsa dan bernegara. Kesimpulannya bahwa nilai karakter generasi muda sangat perlu dilakukan penguatan melalui pendidikan keluarga, sekolah dan masyarakat dengan menggunakan strategi pembiasaan, keteladanan, penghargaan dan hukuman yang bersifat edukatif
\end{abstract}

\section{Kata-kata Kunci: Penguatan Nilai karakter Dan Generasi Muda}




\title{
STRENGTHENING OF YOUNG GENERATION CHARACTER VALUES TO BECOME CAPITAL AND NATIONAL STATE INTEGRATION
}

\author{
Author \\ Nani Mediatati \\ PPKn Study Program Lecturer \\ FKIP-UKSW Salatiga \\ Email: nanimediatati_@gmail.com
}

\begin{abstract}
This study aims to describe the character building of the younger generation whose ethics is Pancasila in diversity. This type of research is library research. The method of data collection is done by reviewing books, research results, papers, theses, theses, dissertations, articles related to the material under study. The data analysis technique was carried out qualitatively by checking selected data from various sources, both online and not. Then the data is displayed, and conclusions drawn. The results of the study based on the assessment of various sources found that there are 18 characters that must be possessed by the younger generation (Kemendikbud) namely; Religious, Honest, Tolerance, Discipline, Hard Work, Creative, Independent, Democratic, Curiosity, National Spirit, Love the Motherland, Appreciate Achievement, Friendly / Communicative, Peaceful Love, Love Reading, Environmental Care, Social Care, Responsibility. Of the 18 values according to Perpres Number 87 Year 2017 concerning Strengthening Character Education, Strengthening Character Education hereinafter referred to as PPK is an educational movement under the responsibility of the education unit to strengthen the character of learners through harmonizing the process of heart, taste, thought, and if body. According to the Presidential Decree there are 5 character values that really need to be done by PPK implemented by applying the values of Pancasila in character education especially covering religious values, honesty, tolerance, discipline, hard working, creative, independent, democratic, curiosity, national spirit, love the motherland, appreciate achievement, communicative, love peace, love to read, care. The five values are strengthened through 3 educational environments namely family, school, and community with strategies: habituation, exemplary, reward and educative punishment. The five character values are strengthened because many phenomena carried out by the young generation in the form of attitudes, behaviors and actions that deviate from the five character values. If not done strengthening can threaten the life of nation and state. The conclusion is that the character value of the younger generation really needs to be strengthened through family, school and community education by using educative, habitual, exemplary, reward and punishment strategies
\end{abstract}

Key Words: Strengthening Character Values and Young Generation 


\section{PENDAHULUAN}

Jati diri bangsa Indonesia meupakan cerminan atau tampilan karakter bangsa Indonesia, dimana karakter bangsa merupakan sinergi dari karakter individu anak bangsa yang berproses secara terus menerus yang mengelompok menjadi bangsa Indonesia. Jati diri yang terpancar beraneka ragam ada yang dominan baik ada yang kurang baik pun ada yang tidak baik yang kesemuanya dipengaruhi oleh lingkungan keluarga, sekolah dan masyarakat.

Ciri-ciri umum bangsa maju yang memiliki karakter baik adalah ramah, santun dan lemah lembut, tidak suka kekerasan, patuh aturan. (Albantani \& Faizi, 2015)Ciri-ciri demikian dapat terwujud manakala keberadaan generasinya berkarakter. Karena itu setiap bangsa berusaha untuk membangun karakter genberasi mudanya dengan memberdayakan tri pilar jalur pendidikan yaitu Keluarga, Sekolah dan Masyarakat.

Bagi bangsa Indonesia upaya mewujudkan generasi berakter mrupakan suatu keharusan karena itu pemerintah mlalui bergai kebijakannya selalu mengedepankan pendidikan karakter bagi generasi muda.. Melalui pendidikan karakter maka dapat dibangun jiwa dan semangat geneerasi muda untuk tetap setia dan bangga terhadap Negara Kesatuan Republik Indonesia.(Muhammad Sulhan, 2018)

Penelitian ini ini difokuskan pada upaya menguatkan nilai karakter generasi muda sebagai modal mewujudkan keutuhan berbangsa dan bernegara. Pokok permasalahan dalam penelitian ini ini dirumuskan bagaimanakah menguatkan nilai karakter generasi muda sebagai modal mewujudkan keutuhan berbangsa dan bernegara ? Tujuan penelitian ini: untuk mendeskripsikan penguatan nilai karakter generasi muda sebagai modal mewujudkan keutuhan berbangsa dan bernegara

\section{KAJIAN PUSTAKA}

Berbicara tentang nilai karakter perlu dipahami konsep dasar terlebih dahulu apa itu nilai dan apa itu karakter.

Terdapat berbagai pengertian nilai yang bervariasi, namun semua maknanya berpengaruh atas aktivitas sehari-hari. Nilai lebih mudah diartikan sebagai gagasan yang dipandang baik dan indah pada kehidupan seseorang. Hanya 
dari nilai saja Anda sudah mampu mengenal karakter orang lain. Agar mampu mengenal lebih jauh tentang nilai, perhatikan penjelasan dibawah ini.

Tidak hanya satu pendapat yang mengartikan pengertian nilai. Lebih dari itu, beberapa ahli mengartikan bahwa nilai adalah proses kehidupan seseorang yang selalu berkembang untuk tatanan hidup. Dibawah ini adalah 10 definisi nilai dari para ahli. SSoerjono Soekamto menganggap bahwa pengertian nilai adalah suatu konsep abstrak yang terdapat pada manusia, hal itu disebabkan atas nilai yang menurutnya baik ataupun jelek sekalipun. Apabila nilai baik pasti menggambarkan kepribadian yang baik, sedangkan nilai buruk akan memunculkan sifat jelek yang kurang disenangi oleh beberapa kelompok. Akibatnya akan menimbulkan masalah baru yang berujung konflik. Pengertian nilai menurut Wood adalah suatu petunjuk dimana kejadiannya berlangsung cukup lama. Dari petunjuk ini, kehidupan seseorang bisa terarahkan hingga mempunyai sifat kepuasan tersendiri. Itu sebabnya Wood mampu membagi nilai dalam dua hal, yaitu nilai baik dan juga nilai jelek. Simanjuntak menyatakan bahwa nilai adalah sekumpulan pemikiran seseorang atas perilaku yang bersifat baik dan buruk. Perilaku tersebut disebabkan adanya tradisi yang dianut oleh masyarakat itu sendiri dan selalu dijalankan secara terus menerus. Sedangkan menurut Robert M.Z.Lawang, nilai adalah pemikiran yang dimiliki setiap orang, namun mampu merubah perilaku sosial dari nilai tersebut. Dari nilai itulah, kehidupan seseorang bisa dilihat, apakah berkarakter baik di lingkungan atau sebaliknya Hendropuspito mengartikan nilai sebagai bentuk penghargaan yang diterima masyarakat atas tatanan hidup yang baik. Hal ini terjadi karena adanya perkembangan hidup yang selalu berubah, sehingga nilai tersebut bisa menjadi pedoman utama dalam berperilaku. Pakar Sosiologi Karel J.Veeger mengemukakan nilai sebagai kriteria seseorang kepada orang lain yang bergantung dari perbuatan dilakukan. Nilai sekaligus dijadikan simbol utama atas perilaku yang dimiliki seseorang. Koentjaraningrat mengartikan nilai sebagai bentuk tradisi yang ada di kehidupan masyarakat. Tradisi ini bisa berubah tergantung dari persepsi orang lain. Apabila dipandang baik, maka semakin baik pula nilai tradisi yang dianut, begitupun sebaliknya. Pengertian nilai yang terakhir adalah dari Green yang menyatakan nilai sebagai tingkat kesadaran setiap individu di lingkungan masing-masing. Dari nilai itulah, seseorang bisa dipandang baik atau buruk. Karena sudah menjadi simbol subjektif yang dimiliki.

Dari berbagai pandangan nilai di atas dapat ditarik benang merah bahwa nilai itu bersifat relative, nilai itu suatu realitas abstrak \&ada dlm kehidupan 
manusia, nilai memiliki sifat normatif,artinya nilai mengandung harapan,citacita,dan suatu keharusan sehingga nilai memiliki sifat ideal (das sollen), nilai berfungsi sebagai daya dorong/motivator \& manusia sebagai pendorong.

Selanjutnya berkaitan dengan karakter ada ebberapa pandangan diantaranya: Maxwell, karakter sebenarnya jauh lebih baik dibandingkan dengan hanya sekedar perkataan. Lebih dari hal itu, karakter sebagai pilihan yang bisa menentukan sebuah tingkat kesuksesan dari seseorang. Menurut Wyne, karakter adalah menandai bagaimana teknis ataupun cara yang digunakan dalam memfokuskan penerapan dari nilai-nilai kebaikan ke dalam sebuah tingkah laku ataupun tindakan. Menurut Kamisa Pengertian karakter adalah sifat kejiwaan, akhlak serta budi pekerti yang dimiliki seseorang yang sehingga membuatnya berbeda dibandingkan dengan orang lainnya. Berkarakater juga bisa diartikanmempunyai sebuah watak serta kepribadian. Menurut Doni Kusuma, Pengertian karakter ialah sebuah gaya, sifat, ciri, ataupun karakteristik yang dimiliki seseorang yang berasal dari pembentukan atau tempaan yang didapatkannya lingkungan yang ada di sekitar. Menurut Gulo W, karakter adalah kepribadian yang bisa dilihat dari titik moral ataupun tolak etis, seperti kejujuran seseorang. Biasanya karakter mempunyai hubungan pada sifat-sifat yang umumnya tetap. Menurut W.B Saunders, karakter ialah sifat yang nyata dan berbeda yang mana ditunjukkan oleh seseorang. karakter tersebut bisa dilihat dari beragam macam atribut di dalam tingkah laku seseorang. Menurut Alwisol, karakter ialah penggambaran dari tingkah laku yang dilakukan dengan memperlihatkan dan menonjolkan nilai, baik itu benar atau salah secara implisit dan eksplisit. Karakter tentu berbeda dengan kepribadian yang memang di dalamnya tidak menyangkut nilai sama sekali.

Berdasarkan konsep dasar nilai dan karakter dapat dirumuskan Nilai-nilai karakter adalah sikap dan perilaku yang didasarkan pada norma dan nilai yang berlaku di masyarakat, yang mencakup aspek spiritual, aspek personal/kepribadian, aspek sosial, dan aspek lingkungan (Direktorat Pembinaan PAUD, 2012:4).

Individu yang berkarakter baik adalah orang yang selalu berusaha dalam melakukan berbagai hal yang terbaik pada Tuhan YME, dirinya sendiri, lingkungannya, orang lain, atau bangsa dan negaranya. Karakter yang baik berarti individu yang tahu tentang potensinya sendiri serta mempunyai nilai-nilai sebagai berikut : 
1. Religius, Sikap serta perilaku yang patuh dalam melaksanakan ajaran agama yang dianutnya, toleran kepada pelaksanaan ibadah agama lain, dan juga mampu hidup rukun dengan pemeluk agama lain.

2. Jujur, Perilaku yang berdasarkan pada upaya menjadikan dirinya sebagai orang yang selalu bisa dipercaya dalam perkataan, tindakan, serta pekerjaan.

3. Toleransi, Sikap serta tindakan yang menghargai perbedaan agama, suku, etnis, pendapat, sikap, dan juga tindakan orang lain yang berbeda dengan dirinya.

4. Disiplin, Tindakan yang menunjukkan perilaku tertib dan juga patuh terhadap berbagai ketentuan serta peraturan.

5. Kerja Keras, Tindakan yang menunjukkan perilaku tertib serta patuh terhadap berbagai ketentuan dan juga peraturan.

6. Kreatif, Berpikir serta melakukan sesuatu untuk menghasilkan cara ataupun hasil baru dari sesuatu yang telah dimiliki.

7. Mandiri, Sikap serta perilaku yang tidak mudah tergantung kepada orang lain dalam menyelesaikan tugas-tugas.

8. Demokratis, Cara berfikir, bersikap, bertindak yang menilai sama hak serta kewajiban dan dirinya orang lain.

9. Rasa Ingin Tahu, Sikap serta tindakan yang selalu berupaya demi mengetahui lebih mendalam dan juga meluas dari sesuatu yang dipelajarinya, dilihat, serta didengar.

10. Semangat Kebangsaan, Cara berpikir, bertindak, serta berwawasan yang menempatkan kepentingan bangsa dan juga negara di atas kepentingan diri atau kelompoknya.

11. Cinta Tanah Air, Cara berpikir, bertindak, serta berwawasan yang menempatkan kepentingan bangsa dan juga negara diatas kepentingan diri dan kelompoknya.

12. Menghargai Prestasi, Sikap dan tindakan yang mendorong dirinya untuk menghasilkan sesuatu yang berguna untuk masyarakat, mengakui, serta menghormati keberhasilan orang lain.

13. Bersahabat/Komunikatif, Sikap dan tindakan yang mendorong dirinya untuk menghasilkan sesuatu yang berguna untuk masyarakat, mengakui, serta menghormati keberhasilan orang lain. 
14. Cinta Damai, Sikap dan tindakan yang mendorong dirinya untuk menghasilkan sesuatu yang berguna untuk masyarakat, mengakui, serta menghormati keberhasilan orang lain.

15. Gemar Membaca, Kebiasaan menyediakan waktu untuk membaca berbagai macam bacaan yang memberikan kebajikan bagi dirinya.

16. Peduli Lingkungan, Sikap dan tindakan yang selalu berupaya mencegah kerusakan terhadap lingkungan alam di sekitarnya, dan juga mengembangkan upaya-upaya untuk memperbaiki kerusakan alam yang sudah terjadi.

17. Peduli Sosial, Sikap serta tindakan yang selalu ingin memberi bantuan kepada orang lain dan juga masyarakat yang membutuhkan.

18. Tanggung Jawab, Sikap serta perilaku seseorang untuk melaksanakan tugas dan juga kewajibannya, yang seharusnya dia lakukan, baik pada diri sendiri, masyarakat, lingkungan (alam, sosial dan budaya), negara dan Tuhan Yang Maha Esa

19. Berpola hidup sehat, Pola hidup sehat adalah sikap untuk selalu berusaha menerapkan pola hidup yang baik, agar bisa menciptakan kehidupan yang sehat dan selalu berusaha untuk menghindari pola hidup buruk.

20. Cinta terhadap ilmu pengetahuan, Hal ini merupakan cara berfikir dalam menunjukan kepedulian yang tinggi pada ilmu pengetahuan yaitu dengan cara mempelajari serta menambah ilmu pengetahuan.

21. Selalu berpikir logis, kritis dan inovatif, Cara berfikir dalam melakukan sesuatu sesuai dengan kenyatan dan jug logika untuk menghasilkan hasil yang baru dan termutakir dari apa yang sudah dimiliki.

Nilai karakter di atas membingkai dalam setiap sikap, perilaku dan perbuatan manusia. (Sumarsono, 2018)Karena itulah manusia diberikan pendidikan karakter. Pendidikan karakter bertujuan untuk mengembangkan nilainilai yang membentuk karakter bangsa yaitu Pancasila yaitu: Mengembangkan potensi peserta didik supaya menjadi manusia berhati baik, berpikiran baik serta berperilaku baik. Membangun bangsa dengan berkarakter Pancasila. Mengembangkan potensi warga negara supaya mempunyai sikap percaya diri, bangsa dan negaranya juga mencintai umat manusia. Menurut Kesuma “2011:9”, Pendidikan karakter ialah sebagai berikut: Meningkatkan dan mengembangkan nilai-nilai kehidupan yang dianggap penting serta perlu sehingga menjadi kepribadian atau kepemilikan peserta didik yang khas sebagaimana nilai-nilai 
yang dikembangkan. Mengoreksi perilaku peserta didik yang tidak sesuai dengan nilai-nilai yang dikembangkan oleh sekolah. Membangun koneksi yang harmoni dengan keluarga dan juga masyarakat dalam memerankan tanggung jawab pendidikan karakter secara bersama. Fungsi pendidikan karakter berdasarkan Panduan Pelaksanaan Pendidikan Karakter "2011" diantaranya yaitu : Membangun kehidupan bangsa yang multikultural. Membangun peradaban bangsa yang cerdas, berbudaya luhur dan juga mampu berkontribusi pada pengembangan kehidupan umat manusia, mengembangkan potensi dasar supaya berhati baik, berpikiran baik, berperilaku baik dan keteladanan yang Membangun sikap warga negara yang cinta damai, kreatif, mandiri serta mampu hidup berdampingan dengan bangsa lainnya dalam suatu harmoni.

Generasi Muda adalah terjemahan dari young generation lawan dari old age. Youth mengandung arti populasi remaja/anak muda/pemuda yang sedang membentuk dirinya. Melihat kata "Generasi muda" yang terdiri dari dua kata yang majemuk, kata yang kedua adalah sifat atau keadaan kelompok individu itu masih berusia muda dalam kelompok usia muda yang diwarisi cita-cita dan dibebani hak dan kewajiban, sejak dini telah diwarnai oleh kegiatan-kegiatan kemasyarakatan dan kegiatan politik. Maka dalam keadaan seperti ini generasi muda dari suatu bangsa merupakan "Young Citizen". Pengertian generasi muda erat hubungannya dengan arti generasi muda sebagai generasi penerus. Yang dimaksud "Generasi Muda" secara pasti tidak terdapat satu definisi yang dianggap paling tepat akan tetapi banyak pandangan yang mengartikannya tergantung dari sudut mana masyarakat melihatnya. Namun dalam rangka untuk pelaksanaan suatu program pembinaan bahwa "Generasi Muda" ialah bagian suatu generasi yang berusia 0 30 tahun.

Dilihat dari segi biologis, ada istilah bayi, anak, remaja, pemuda dan dewasa. Anak 1- 12 tahun, remaja 12 - 15 tahun, pemuda 15- 30 tahun, dewasa 30 tahun ke atas. Untuk kepentingan perencanaan modern digunakan istilah sumber-sumber daya manusia muda (Young human resources) sebagai salah satu dari 3 sumber-sumber pembangunan yaitu: sumber-sumber alam (natural resources) sumber-sumber dana (financial resources) sumber-sumber daya manusia (human resources) (Agustin, 2011).Yang dimaksud dengan sumbersumber daya manusia muda adalah dari 0 - 18 tahun.

Dilihat dari sudut ideologis-politis, maka generasi muda adalah calon pengganti generasi terdahulu dalam hal ini berumur antara 18 sampai 30 tahun, dan kadang-kadang sampai umur 40 tahun. (Yakan, 2005) Pengertian pemuda 
berdasarkan umur dan lembaga serta ruang lingkup tempat pemuda berada. Diperoleh 3 kategori: Siswa usia antara 6 - 18 tahun, yang masih ada dibangku sekolah Mahasiswa di Universitas atau perguruan tinggi, yang berusia antara 1821 tahun. Pemuda di luar lingkungan sekolah maupun perguruan tinggi yang berusia antarea 15-30 tahun.

Pemuda adalah generasi penerus bangsa, dimana sosok pemuda diharapkan dapat melanjutkan perjuangan dari generasi sebelumnya. (Yoga Agustin, 2011) Suatu bangsa pastinya memiliki harapan yang besar agar pada masa yang akan datang para pemuda dapat menjadikan bangsa Indonesia ini bangsa yang lebih maju. Hal tersebut diperkuat dengan pendapat bahwa pemuda merupakan lapisan eksponental bangsa, yang berjumlah 30\% dari jumlah seluruh bangsa Indonesia dan merupakan lapisan yang penuh dengan dinamisme, vitalitas heroisme (Surakhman, 1980:4). Oleh karenanya para para pemuda ini memiliki beban untuk mewujudkan harapan dan citacita bangsa dari generasi sebelumnya. Tetapi jika dikaji secara mendalam tidak semua pemuda memiliki cita-cita luhur untuk menjadikan bangsa ini bangsa yang lebih maju. Masih banyak pemuda di bangsa ini yang berbuat tidak sesuai dengan harapan generasi sebelumnya. Dapat kita lihat bahwa banyak pemuda yang sekarang ini justru melakukan hal-hal yang tidak seharusnya dilakukan oleh suatu generasi harapan bangsa. Bahkan sekarang ini banyak pemuda yang justru merusak masa depan mereka sendiri. Beberapa persoalan yang memberikan bukti bahwa generasi pemuda saat ini bertindak melawan norma-norma yang ada, diantaranya ada sebagian pemuda yang senang mengkonsumsi minuman keras, mengkonsumsi narkoba, melakukan tindak kriminal seperti memperkosa, mencuri, mencopet bahkan merampok. Hal tersebut diperkokoh dengan adanya artis yang belum mampu dijadikan sebagai public figure seperti yang dapat kita lihat seperti Revaldo seorang artis yang ditangkap oleh pihak kepolisian karena mengkonsumsi narkoba, begitu juga dengan artis lain seperti Sammy Simorangkir yang juga tersandung masalah narkoba. Selain itu masih banyak lagi perbuatan- perbuatan yang tidak seharusnya dilakukan oleh pemuda sebagai generasi bangsa.

Sekarang ini banyak organisasi kepemudaan yang dapat dijadikan sebagai wadah pengembang nilai karakter pada pemuda. Contohnya seperti organisasi- organisasi keagamaan seperti remaja masjid, ataupun organisasi lain seperti perkumpulan pemuda pecinta motor, organisasi pemuda pecinta alam ataupun organisasi yang berdiri di suatu wilayah tertentu seperti di kecamatan, kelurahan ataupun di suatu dukuh atau RT seperti organisasi kepemudaan karang taruna. 
Penanaman nilai-nilai karakter pada diri pemuda dapat dilaksanakan melalui berbagai kegiatan kepemudaan . Generasi muda sekarang ini menjadi bahan pembicaraan oleh semua kalangan masyarakat, karena generasi muda adalah generasi penerus bangsa yang nantinya sebagai pemegang nasib bangsa ini, maka generasi mudalah yang menentukan semua apa yang dicitacitakan bangsa dan Negara ini.

Pemuda diharapkan mampu bertanggung jawab dalam membina kesatuan dan persatuan, serta mengamalkan nilai-nilai yang ada di dalam pancasila agar terciptanya kedamaian, kesejahteraan umum, serta kerukunan antar bangsa.Yang paling penting nasib bangsa Indonesia baik buruknya ke depan itu akan sangat bergantung pada generasi penerusnya yaitu generasi muda yang bermartabat.

Masalah pemuda merupakan masalah yang abadi dan selalu dialami oleh setiap generasi dalam hubungannya dengan generasi yang lebih tua. Problem itu disebabkan karena akibat dari proses pendewasaan seseorang, penyesuaian dirinya dengan situasi yang baru timbulah harapan setiap pemuda akan mempunyai masa depan yang lebih baik dari pada orang tuanya. Masalah antar generasi merupakan salah satu kesalahan masyarakat yang dikenal sejak dulu kala. Yang dipernasalahkan adalah nilai-nilai masyarakat. Pada umumnya dapat dikatakan bahwa masalah antar generasi mencerminkan bagaimana kebudayaan masyarakat itu sendiri. Sehubungan dengan ini para ahli sosial berpendapat bahwa masalah antar generasi kurang dan hampir tidak terdapat dimasyarakat tradisional. Dengan demikian dapatlah dikatakan bahwa antar generasi merupakan suatu masalah modern. Berbagai macam permasalahan generasi muda yang muncul pada saat ini antara lain :(Mustari et al., 2004)

a. Menurunnya jiwa idealisme, patriotisme dan nasionalisme dikalangan masyarakat termasuk jiwa pemuda.

b. Kekurang pastian yang dialami oleh generasi muda terhadap masa depannya.

c. Belum keseimbangannya antara jumlah generasi muda dengan fasilitas pendidikan yang tersedia, baik yang formal maupun non formal.

d. Kekurangan lapangan dan kesempatan kerja serta tinggi nya tingkat pengangguran dan setengah pengangguran dikalangan generasi muda mengakibatkan berkurangnya produktifitas oleh nilai-nilai kekuasaan dan sebagainya.

e. Masih langkanya pengalaman-pengalaman yang dapat merelefansikan pendapat sikap dan tindakanya dengan kenyataan yang ada. 
f. Menurunnya jiwa idealisme, patriotisme dan nasionalisme dikalangan masyarakat termasuk jiwa pemuda.

g. Kekurang pastian yang dialami oleh generasi muda terhadap masa depannya.

h. Belum keseimbangannya antara jumlah generasi muda dengan fasilitas pendidikan yang tersedia, baik yang formal maupun non formal.

i. Kekurangan lapangan dan kesempatan kerja serta tinggi nya tingkat pengangguran dan setengah pengangguran dikalangan generasi muda mengakibatkan berkurangnya produktifitas oleh nilai-nilai kekuasaan dan sebagainya.

j. Masih langkanya pengalaman-pengalaman yang dapat merelefansikan pendapat sikap dan tindakanya dengan kenyataan yang ada.

Dengan demikian bagaimana semua masalah itu agar dapat dipecahkan olah masyarakat merupakan cerminan kebudayaan masyarakat itu sendiri. Peranan dimasyarakat

Masa depan suatu bangsa terletak pada generasi mudanya sebab merekalah yang menggantikan generasi sebelumnya dalam memimpin bangsa oleh karena itu generasi muda perlu diberi bekal berupa ilmu pengetahuan sesuai dengan tuntunan zaman. Salah satu cara dalam memperoleh bekal pengetahuan tersebut dapat melalui pendidikan baik formal maupun nonformal baik itu pendidikan dasar maupun pendidikan tinggi.

Hal-hal yang menghambat kemajuan harus diganti dengan hal-hal baru sesuai dengan tuntunan dan perkembangan masyarakat. Oleh karena itu dalam mengadakan perubahan hendaknya memperhatikan situasi dan kondisi mereka berada.

Pembagunan yang kita laksanakan itu jelas merupakan rangkaian gerakan perubahan menuju kemajuan. Dalam beberapa hal, perubahan itu merupakan perombakan yang sangat mendasar. Perubahan atau kemajuan dalam pembangunan bukan hanya perubahan fisik saja tetapi membawa serta perubahan sosial. Perubahan sosial itu mengandung kekuatan dinamika karena mnyangkut tata nilai, sikap dan tingkah laku. Dengan kata lain pembangunan memerlukan pembaruan.

Pembangunan tidak akan berjalan lancar jika manusia tidak giat bekerja oleh karena itu pembangunan adalah penggantian yang lama dengan yang baru, yang telah diperhitungkan oleh keadaan sekitarnya, maka mahasiswa berkewajiban untuk ikut serta dalam derap pembangunan. Disamping itu 
mahasiswa bertugas sebagai pelopor pembangunan sehingga perlu difikirkan kesesuaian macam pembaruan dengan lingkungan masyarakat sekitarnya. Meskipun hal-hal baru itu tidak selalu membawa kebahagiaan kepada masyarakat, bahkan kadang-kadang dapat menjerumuskan masyarakat ketingkat kehidupan yang kurang baik. Oleh karena itu mahasiswa yang telah dibekali ilmu pengetahuan tang tinggi hendaknya dapat memilih mana-mana yang perlu diubah dan tidak perlu diubah disamping itu perlu dipikirkan keikutsertaan masyarakat dalam pembaharuan tersebut. Dengan demikian, hasilnya akan seperti yang diharapkan.

Masalah generasi muda dalam masyarakat erat kaitannya dengan sosialisasi dan modernisasi. Sosialisasi adalah proses penanaman nilai dan aturan dari satu generasi ke generasi lainnya dalam sebuah masyarakat. Berdasarkan jenisnya sosialisasi dibagi menjadi dua yaitu sosialisasi primer dan sekunder. Sedangkan modernisasi yaitu proses menuju masyarakat yang modern, modernisasi dapt pula berarti perubahan dari masyarakat tradisional menuju masyarakat yang modern. Adapun proses sosialisasi yang keliru dapat menyebabkan penyimpangan. Faktor penyebab penyimpangan yaitu:

a. Tidak adanya nilai dan norma: ukuran perilaku menyimpang bukan pada ukuran baik buruk atau benar salah menurut pengertian umum, melainkan berdasar ukuran longgar atau tidaknya norma dan nilai sosial masyarakat

b. Penyalahgunaan peran: otoritas kekuasaan dan status yang dimiliki oleh seseorang kelompok tertentu di masyarakat yang seluruhnya menjadi contoh yang baik, tetapi melakukan tindakan penyalahgunaan dengan mengabaikan norma

c. Psikologis: menjelaskan sebab terjadinya penyimpangan ada kaitannya dengan kepribadian yang memiliki kecenderungan untuk melakukan penyimpangan

Kurangnya kontrol sosial atau pengawasan terhadap pelaksanaan norma dan nilai yang berlaku di masyarakat.

Meskipun permasalahan yang dihadapi generasi muda sangat kompleks akan tetapi generasi muda memiliki Potensi yang perlu dikembangkan adalah sebagai berikut :

a. Idealisme dan daya kritis

Secara sosiologis generasi muda belum mapan dalam tatanan yang ada sehingga dia dapat melihat kekurangan dalam tatanan tersebut dan 
secara wajar mampu mencari gagasan baru sebagai alternatif kearah perwujudan kearah tatanan yang lebih baik

b. Dinamika dan kreatifitas

Adanya idealisme pada generasi muda mnyebabkan mereka mimiliki potensi kedinamisan dan kreatifitas, yakni kemampun dan kesediaan untuk mengadakan perubahan, pembaharuan dan penyempurnaan kekurangan yang ada ataupun mengungkapkan gagasan yang baru

c. Keberanian mengambil resiko

Perubahan dan pembaharua termasuk pembangunan mengandung resiko dapat meleset terhambat atau gagal. Namun mengambil resiko itu diperlukan jika ingin memperoleh kemajuan.

d. Optimis dan kegairahan semangat

Kegagalan tidak menyebabkan generasi mudah patah semangat. Optimisme dan kegairahan semangat yang dimiliki generasi muda merupakan daya pendorong untuk mencoba maju lagi.

e. Sikap kemandirian dan disiplin murni

Generasi memiliki keinginan untuk selalu mandiri dalam sikap dan tindakannya. Sikap kemandirian itu perlu dilengkapi kesadaran disiplin murni pada dirinya agar mereka dapat menyadari batas-batas yang wajar dan memiliki tenggang rasa.

f. Terdidik

Walaupun dengan memperhitungkan faktor putus sekolah, secara menyeluruh baik dalam arti kuantitatif maupun dalam arti kualitatif, generasi muda secara relatif lebih terpelajar karena lebih terbukanya kesempatan belajar dari generasi pendahulunya.

g. Keanekaragaman dalam persatuan dan kesatuan

Keanekaragaman generasi muda merupakan cermin keanekaragaman masyarakat kita. Keanekaragaman tersebut dapat menjadi hambatan jika dihayati secara sempit dan eksklusif, tapi dapat merupakan potensi dinamis dan kreatif sehingga merupakan sumber yang besar untuk kemajuan bangsanya. Maka para pemuda dapat didorong untuk menampilkan potensinya yang terbaik dan diberi peran yang jelas serta bertanggung jawab dalam menuju cita-cita bangsa.

h. Patriotisme dan Nasionalisme

Pemupukan rasa kebangsaan, kecintaan dan turut memiliki bangsa dan negara dikalangan pemuda perlu ditingkatkan 
i. Fisik kuat dan jumlah banyak

Potensi ini merupakan kenyataan sosiologis dan demografis. Dapat dimanfaatkan dalam kegiatan pembangunan bangsa dan negaranya yang menghendaki pengarahan tenaga dalam jumlah besar.

j. Sikap kesatria

Kemurnian idealisme, keberanian, semangat pengabdian dan pengorbanan serta rasa tanggung jawab sosial yang tinggi adalah unsur-unsur yang perlu dipupuk dan dikembangkan terus menjadi sikap kesatria

k. Kemampuan penguasaan ilmu dan teknologi

Para pemuda dapat berperan secara berdaya guna dalam rangka pengembangan ilmu dan teknologi secara fungsional dapat dikembangkan sebagai transformator terhadap lingkungannya

Masa depan suatu bangsa terletak pada generasi mudanya sebab merekalah yang menggantikan generasi sebelumnya dalam memimpin bangsa oleh karena itu generasi muda perlu diberi bekal berupa ilmu pengetahuan sesuai dengan tuntunan zaman. Salah satu cara dalam memperoleh bekal pengetahuan tersebut dapat melalui pendidikan baik formal maupun nonformal baik itu pendidikan dasar maupun pendidikan tinggi.

Hal-hal yang menghambat kemajuan harus diganti dengan hal-hal baru sesuai dengan tuntunan dan perkembangan masyarakat. Oleh karena itu dalam mengadakan perubahan hendaknya memperhatikan situasi dan kondisi mereka berada.

Pembagunan yang kita laksanakan itu jelas merupakan rangkaian gerakan perubahan menuju kemajuan. Dalam beberapa hal, perubahan itu merupakan perombakan yang sangat mendasar. Perubahan atau kemajuan dalam pembangunan bukan hanya perubahan fisik saja tetapi membawa serta perubahan sosial. Perubahan sosial itu mengandung kekuatan dinamika karena mnyangkut tata nilai, sikap dan tingkah laku. Dengan kata lain pembangunan memerlukan pembaruan.

Pembangunan tidak akan berjalan lancar jika manusia tidak giat bekerja oleh karena itu pembangunan adalah penggantian yang lama dengan yang baru, yang telah diperhitungkan oleh keadaan sekitarnya, maka mahasiswa berkewajiban untuk ikut serta dalam derap pembangunan. Disamping itu mahasiswa bertugas sebagai pelopor pembangunan sehingga perlu difikirkan 
kesesuaian macam pembaruan dengan lingkungan masyarakat sekitarnya. Meskipun hal-hal baru itu tidak selalu membawa kebahagiaan kepada masyarakat, bahkan kadang-kadang dapat menjerumuskan masyarakat ketingkat kehidupan yang kurang baik. Oleh karena itu mahasiswa yang telah dibekali ilmu pengetahuan tang tinggi hendaknya dapat memilih mana-mana yang perlu diubah dan tidak perlu diubah disamping itu perlu dipikirkan keikutsertaan masyarakat dalm pembaharuan tersebut. Dengan demikian, hasilnya akan seperti yang diharapkan.

\section{METODE}

Penelitian ini termasuk jenis penelitian kepustakaan. Noeng Muhadjir (1996:169) Penelitian kepustakaan yaitu penelitian yang lebih memerlukan olahan filosofis dan teoritis daripada uji empiris dilapangan. Karena sifatnya yang teoritis dan filosofis, penelitian kepustakaan lebih sering menggunakan pendekatan filosofis (philosophical approach) dibandingkan pendekatan yang lain. Metode penelitian kepustakaan mencakup sumber data, pengumpulan data, dan analisis data.(Danandjaja, 2014) (Setiawan, 2017) Mardalis Penelitian kepustakaan dapat didefinisikan sebagai penelitian yang bertujuan untuk mengumpulkan data dan informasi melalui bantuan bermacam-macam material yang terdapat di ruangan perpustakaan, misalnya: buku-buku, majalah, dokumen, catatan dan kisah-kisah sejarah dan lain-lainnya. Pada hakekatnya data yang diperoleh melalui penelitian perpustakaan bisa dijadikan landasan dasar dan alat utama bagi pelaksanaan penelitian lapangan. Mardalis juga mengemukakan bahwa penelitian ini sebagai penelitian yang membahas data-data sekunder. Namun I Made Wirartha Penelitian kepustakaan merupakan penelitian yang dapat dilakukan di perpustakaan atau di tempat lain selama ada sumber bacaan yang relevan. Mustika Zed Mustika Zed mengemukakan tiga alasan dalam menggunakan penelitian pustaka, yaitu: Persoalan penelitian tersebut hanya dapat dijawab melalui penelitian pustaka dan sebaliknya tidak mungkin mengharapkan datanya dari penelitian lapangan. Penelitian dalam bidang sejarah umumnya menggunakan metode library research, selain itu penelitian studi agama dan sastra juga menggunakan metode ini. Studi kasus dalam pustaka dibutuhkan sebagai salah satu tahap tersendiri, yaitu studi pendahuluan (prelinmary research) untuk memahami gejala baru secara lebih mendalam yang tengah berkembang di lapangan atau dalam masyarakat. Misalnya Ahli kedokteran atau biologi melakukan riset pustaka untuk mengetahui sifat dan jenis-jenis virus atau bakteri 
penyakit yang belum dikenal. Data pustaka tetap andal untuk menjawab persoalan penelitiannya. Bukankah perpustakaan adalah tambang emas yang sangat kaya untuk riset ilmiyah. Informasi atau data empiris yang sudah dikumpulkan orang lain, misalnya berupa laporan hasil penelitian atau laporan-laporan resmi, bukubuku yang tersimpan dalam perpustakaan tetap bisa digunakan oleh peneliti kepustakaan.

Penelitian kepustakaan memiliki empat ciri utama, yaitu: Peneliti berhadapan langsung dengan teks (nash) atau data angka dan bukan dengan pengetahuan langsung dari lapangan atau saksi mata (eyewitness) yang berupa kejadian,orang atau benda-benda lainnya. Data pustaka bersifat 'siap pakai' (ready made). Ini artinya yaitu peneliti tidak pergi kemana mana, kecuali hanya berhadapan langsung dengan bahan sumber yang sudah tersedia di perpustakaan. Data pustaka umumnya berupa sumber sekunder, yang berarti bahwa peneliti mendapatkan bahan dari tangan kedua dan bukan data orisinil dari tangan pertama di lapangan. Kondisi data pustaka tidak dibatasi oleh ruang dan waktu. Peneliti berhadapan dengan informasi statis, tetap.

Metode pengumpulan data dilakukan dengan mengkaji buku-buku, hasil penelitian, makalah, skripsi, thesis, desertasi, artikel yang berkaiatn dengan materi yang diteliti. Teknik analisis data dilakukan secara kualitatif yaitu mengkroscekkan data-data terseleksi dari berbagai sumber baik yang on line maupun tidak. Selanjutnya dilakukan display data, dan penarikan kesimpulan.(Mirzaqon \& Purwoko, 2018)

\section{HASIL PENELITIAN DAN PEMBAHASAN}

Pendidikan karakter pada Generasi Muda, dewasa ini sangat di perlukan di karenakan saat ini Bangsa Indonesia sedang mengalami krisis karakter dalam diri anak bangsa. Karakter di sini adalah watak, tabiat, akhlak, atau kepribadian seseorang yang terbentuk dari hasil internalisasi berbagai kebajikan yang diyakini dan digunakan sebagai landasan untuk cara pandang, bepikir, bersikap dan bertindak. Kebajikan tersebut berupa Sejumlah nilai moral, dan norma, seperti jujur, berani bertindak, dapat dipercaya, hormat pada orang lain, disiplin, mandiri, kerja keras, kreatif.

Berbagai permasalahan yang melanda bangsa belakangan ini ditengarai karena jauhnya kita dari karakter. Jati diri bangsa seolah tercabut dari akar yang sesungguhnya. Sehingga pendidikan karakter menjadi topik yang hangat di bicarakan belakangan ini.Menurut Prof Suyanto Ph.D dalam web yang penulis 
akses, karakter adalah cara berpikir dan berperilaku yang menjadi ciri khas tiap individu untuk hidup dan bekerja sama, baik dalam lingkup keluarga, masyarakat, bangsa dan negara. Individu yang berkarakter baik adalah individu yang bisa membuat keputusan dan siap mempertanggungjawabkan tiap akibat dari keputusan yang ia buat.

Pembentukan karakter merupakan salah satu tujuan pendidikan nasional. Pasal I UU Sisdiknas tahun 2003 menyatakan bahwa di antara tujuan pendidikan nasional adalah mengembangkan potensi peserta didik untuk memiliki kecerdasan, kepribadian dan akhlak mulia. Amanah UU Sisdiknas tahun 2003 itu bermaksud agar pendidikan tidak hanya membentuk insan Indonesia yang cerdas, namun juga berkepribadian atau berkarakter, sehingga nantinya akan lahir generasi bangsa yang tumbuh berkembang dengan karakter yang bernafas nilainilai luhur bangsa serta agama.

Pendidikan karakter di nilai sangat penting untuk di mulai pada anak usia dini atau Sekolah Dasar karena pendidikan karakter adalah proses pendidikan yang ditujukan untuk mengembangkan nilai, sikap, dan perilaku yang memancarkan akhlak mulia atau budi pekerti luhur. Nilai-nilai positif dan yang seharusnya dimiliki seseorang menurut ajaran budi pekerti yang luhur adalah amal saleh, amanah, antisipatif, baik sangka, bekerja keras, beradab, berani berbuat benar, berani memikul resiko, berdisiplin, berhati lapang, berhati lembut, beriman dan bertaqwa, berinisiatif, berkemauan keras, berkepribadian, berpikiran jauh ke depan, bersahaja, bersemangat, bersifat konstruktif, bersyukur, bertanggung jawab, bertenggang rasa, bijaksana, cerdas, cermat, demokratis, dinamis, efisien, empati, gigih, hemat, ikhlas, jujur, kesatria, komitmen, kooperatif, kosmopolitan (mendunia), kreatif, kukuh hati, lugas, mandiri, manusiawi, mawas diri, mencintai ilmu, menghargai karya orang lain, menghargai kesehatan, menghargai pendapat orang lain, menghargai waktu, patriotik, pemaaf, pemurah, pengabdian, berpengendalian diri, produktif, rajin, ramah, rasa indah, rasa kasih sayang,rasa keterikatan, rasa malu, rasa memiliki, rasa percaya diri, rela berkorban, rendah hati, sabar, semangat kebersamaan, setia, siap mental, sikap adil, sikap hormat, sikap nalar, sikap tertib, sopan santun, sportif, susila, taat asas, takut bersalah, tangguh, tawakal, tegar, tegas, tekun, tepat janji, terbuka, ulet, dan sejenisnya.

Sejatinya pendidikan karakter ini memang sangat penting dimulai sejak dini. Sebab falsafah menanam sekarang menuai hari esok adalah sebuah proses yang harus dilakukan dalam rangka membentuk karakter anak bangsa. Pada usia kanak-kanak atau yang biasa disebut para ahli psikologi sebagai usia emas (golden 
age) terbukti sangat menentukan kemampuan anak dalam mengembangkan potensinya. Hasil penelitian menunjukkan bahwa sekitar 50 persen variabilitas kecerdasan orang dewasa sudah terjadi ketika anak berusia empat tahun. Peningkatan 30 persen berikutnya terjadi pada usia delapan tahun, dan 20 persen sisanya pada pertengahan atau akhir dasawarsa kedua.

Dari sini, sudah sepatutnya pendidikan karakter dimulai dari dalam keluarga, yang merupakan lingkungan pertama bagi pertumbuhan karakter anak. Setelah keluarga, di dunia pendidikan karakter ini sudah harus menjadi ajaran wajib sejak sekolah dasar.

Anak-anak adalah generasi yang akan menentukan nasib bangsa di kemudian hari. Karakter anak-anak yang terbentuk sejak sekarang akan sangat menentukan karakter bangsa di kemudian hari. Karakter anak-anak akan terbentuk dengan baik, jika dalam proses tumbuh kembang mereka mendapatkan cukup ruang untuk mengekspresikan diri secara leluasa.

Pendidikan karakter menjadi hal yang sangat mendesak mengingat buah pendidikan beroleh hasil yang kurang optimal hal ini dapat dibuktikan dengan demoralisasi moral dan degradasi pengetahuan yang sudah menjadi akut menjangkit bangsa ini di semua lapisan masyarakat.

Pendidikan karakter adalah pemberian pandangan mengenai berbagai jenis nilai hidup, seperti kejujuran, kecerdasan, kepedulian, tanggung jawab, kebenaran, keindahan, kebaikan, dan keimanan. Dengan demikian, pendidikan berbasis karakter dapat mengintegrasikan informasi yang diperolehnya selama dalam pendidikan untuk dijadikan pandangan hidup yang berguna bagi upaya penangggulangan persoalan hidupnya.

Pendidikan berbasis karakter diprogram untuk upaya kesadaran normatif yang ada pada hati nurani supaya diteruskan kepada pikiran untuk dicari rumusan bentuk perilaku, kemudian ditransferkan keanggota badan pelaksana perbuatan. Contoh, mulut pelaksana perbuatan bicara atau bahasa melalui kata-kata, maka sistem mulut memfungsikan kata-kata bersifat logis atau masuk akal, bahkan dengan landasan kesadaran norma dan tanggung jawab akan terjadi komunikasi dengan perkataan santun yang jauh dari celaan dan menyakitkan orang lain. Karena itu, pendekatan proses pembelajaran di sekolah perlu disesuaikan.Yaitu dengan menciptakan iklim yang merangsang pikiran peserta didik untuk digunakan sebagai alat observasi dalam mengeksplorasi dunia. 
Baik dan buruknya generasi muda m,enjadi tanggung jawab bersama antara keluarga, sokolah dan masyarakat. Karena itu pembinaan terhadap generasi muda pun juga menjadi tanggung jawab bersama.

Di sadari atau tidak bahwa perkembangan global memiliki dampak positif dan negative bagi generasi muda artinya bahwa perkembangan global disamping mmemberikan peluang sekaligus tantangan bagi generasi muda. Kita tidak dapat menjauhkan diri generasi muda dari perkembangan global akan tetapi juga tidak dapat memberikan kebebasan kepada generasi muda dalam menerima perkembangan global. Sikap selektif sangat diperlukan artinya bahwa perkembangan global tetap well come akan tetapi ahrus difilter dengan nilai-nilai kepribadian bangsa yang bersumberkan pada nilai-nilai pancasila.

Nilai-nilai yang bersumberkan pada pancasila mencakup 5 nilai yaitu: nilai ketuhanan, nilai kemanusiaan, nilai persatuan, nilai kerakyatan dan nilai keadilan. Setiap nilai memiliki ruang linbgkup yang berbeda satu dengan lainnya.

Dalam hidup berbangsa dan bernegara, sebagai warga negara Indonesia kita harus berpegang teguh pada Pancasila yang mana itu adalah ideologi dasar negara kita. Pancasila sebagai pedoman bagi seluruh warga negara Indonesia seharusnya lebih dari cukup untuk menjadi arah hidup kita dalam berbangsa dan bernegara. Namun sebelum menerapkan nya kedalam bermasyarakat maka kita harus tau makna yang terkandung dalam simbo-simbol sila pancasila.

Sila pertama yaitu Ketuhanan Yang Maha Esa, Pada sila pertama pancasila bangsa Indonesia harus memiliki agama ataupun kepercayaan dalam memeluk dan beribadah sesuai dengan iman agama masing-masing. Seharusnya dalam sila pertama ini, warga Negara Indonesia sudah jelas dan mengerti tentang Tuhan Yang Maha Esa. Meyakini bahwa perbuatan dan sikap kita pasti akan diperhatikan oleh Tuhan kita masing-masing. Bangsa harus berusaha memberantas aliran aliran keagamaan yang menyimpang terhadap nilai-nilai maupun moral pancasila. Tetapi pada kenyataannya masih banyak orang yang melakukan penyimpangan dari nilai-nilai pancasila tanpa pengawasan dari Tuhan Yang Maha Mengetahui. Kenyataannya masih banyak kebohongan, kecurangan, konspirasi, dan masih banyak hal lainnya yang diperbuat oleh manusia. Sebagai contoh kecil yaitu masih banyak pelajar yang berbuat kecurangan dalam pembelajaran seperti mencontek, membuat cara apapun untuk mendapatkan jawaban saat ujian, dan masih banyak lagi. Juga seperti koruptor, yang berbuat seenaknya merampas uang yang bukan haknya. Hal-hal tersebut menandakan bahwa orang tersebut merasa tidak diawasi oleh Tuhan mereka. 
Kemudian mengembangkan sikap hormat menghormati dan bekerjasama antara pemeluk agama dengan penganut kepercayaan yang berbeda-beda terhadap Tuhan Yang Maha Esa. Membina kerukunan hidup di antara sesama umat beragama dan kepercayaan terhadap Tuhan Yang Maha Esa. Akur dalam bermasyarakat sebagai umat beragama saling menghormati kehendak beribadah satu sama lain sesuai agama yang sah di Indonesia. Tidak menghalang-halangi umat beragama lain untuk beribadah dan berdakwah masing-masing asalkan masih dalam norma-norma yang berlaku.

Sila kedua yaitu Kemanusian yang adil dan beradab, mengakui dan memperlakukan manusia sesuai dengan harkat dan martabatnya sebagai makhluk Tuhan Yang Maha Esa. Mengakui persamaan derajat, persamaan hak, dan kewajiban asasi setiap manusia, tanpa membeda-bedakan suku, keturunan, agama, kepercayaan, jenis kelamin, kedudukan sosial, warna kulit dan sebagainya. Tidak merendahkan orang lain dengan mudah tetapi bersikaplah rendah diri agar tidak menimbulkan perpecahan satu sama lain. Menjunjung tinggi nilai-nilai kemanusiaan, mengembangkan sikap saling mencintai sesama manusia, sikap saling tenggang rasa dan tepa selira, dan sikap tidak semenamena terhadap orang lain. Mulailah menghargai satu sama lain memberikan perhatian kepada mereka yang mengalami kesusahan.

Makna dari sila ini diharapkan dapat mendorong seseorang untuk senantiasa menghormati orang lain sebagai pribadi dan anggota masyarakat. Dengan sikap ini diharapkan dapat menyadarkan bahwa dirinya merupakan makhluk sosial yang mempunyai hak dan kewajiban yang sama, atas dasar sikap prikemanusian ini.

Sila ketiga yaitu Persatuan Indonesia, maksud dari sila ketiga ini mengutamakan persatuan atau kerukunan bagi seluruh rakyat Indonesia yang mempunyai perbedaan agama, suku, Bahasa dan budaya. kita sebagai warga negara Indonesia harus mampu menempatkan persatuan, kesatuan, serta kepentingan dan keselamatan bangsa dan negara sebagai kepentingan bersama di atas kepentingan pribadi dan golongan. Sanggup dan rela berkorban untuk kepentingan negara dan bangsa apabila diperlukan. Perlu dijelaskan bahwa sudah tidak sedikit lagi orang-orang yang sudah hilang rasa persatuan dan nasionalisme, mulai acuh tak acuh apa yang terjadi pada negara kita. Mengembangkan rasa cinta kepada tanah air dan bangsa dan mengembangkan rasa kebanggaan berkebangsaan dan bertanah air Indonesia. Mulailah dengan cara mencintai produk Indonesia, Memelihara ketertiban dunia yang berdasarkan 
kemerdekaan, perdamaian abadi, dan keadilan sosial. Mengembangkan persatuan Indonesia atas dasar Bhinneka Tunggal Ika dan memajukan pergaulan demi persatuan dan kesatuan bangsa. Menjalin hubungan baik antara negara lain, tidak saling menjatuhkan dan menimbulkan perselisihan.

Sila keempat yaitu Kerakyatan yang dipimpin oleh hikmat kebijaksanaan dalam permusyawaratan/perwakilan. Sila keempat ini mempunyai makna bahwa kekuasaan ada ditangan rakyat, dan dalam melaksanakan kekuasaannya, rakuat menjalankan sistem perwakilan dan keputusan-keputusan yang diambil dilakukan dengan jalan musyawarahyang dikendlikan dengan pikiran yang sehat, jernih, logis serta penuh tanggung jawab baik.

Menerapkan sila keempat ini kita sebagai warga negara dan warga masyarakat, setiap manusia Indonesia mempunyai kedudukan, hak, dan kewajiban yang sama dan tidak boleh memaksakan kehendak kepada orang lain. Mengutamakan musyawarah dalam mengambil keputusan untuk kepentingan bersama , mencapai mufakat diliputi oleh semangat kekeluargaan, menghormati dan menjunjung tinggi setiap keputusan yang dicapai sebagai hasil musyawarah dengan iktikad baik dan rasa tanggung jawab menerima dan melaksanakan hasil keputusan musyawarah. Di dalam musyawarah diutamakan kepentingan bersama di atas kepentingan pribadi dan golongan, Musyawarah dilakukan dengan akal sehat dan sesuai dengan hati nurani yang luhur. Keputusan yang diambil harus dapat dipertanggungjawabkan secara moral kepada Tuhan Yang Maha Esa, menjunjung tinggi harkat dan martabat manusia, nilai-nilai kebenaran dan keadilan mengutamakan persatuan dan kesatuan demi kepentingan bersama. Memberikan kepercayaan kepada wakil-wakil yang dipercayai untuk melaksanakan pemusyawaratan. Tetapi saat ini banyaknya krisis kepercayaan, banyak orang yang dipercaya tetapi ingkar. Oleh sebab itu saat ini sudah kurangnya kepercayaan satu sama lain.

Sila kelima yaitu Keadilan sosial bagi seluruh rakyat Indonesia. Keadilan berarti adanya persamaan dan saling menghargai karya orang lain. Jadi seseorang itu bertindak adil apabila orang memberikan sesuatu kepada orang lain sesuai dengan haknya.

Kemakmuran yang merata bagi seluruh rakyat dalam arti dinamis dan meningkat. Dinamis dalam arti diupayakan lebih tinggi dan lebih baik. Hal ini berarti peningkatan kesejahteraan dan kemakmuran yang lebih baik. Seluruh kekayaan alam tidak dikuasai oleh sekelompok orang, tetapi harus untuk kesejahteraan semua orang, kepentingan bersama menurut potensi masing- 
masing. Jadi sesuatu yang diberikan kepada seseorang sesuai dengan kemampuan, sesuai dengan potensinya utulh yang disebut adil.

Keadilan sosial bagi seluruh rakyat Indonesia memiliki makna yang sangat luas seperti kekeluargaan dan kegotongroyongan, sikap adil terhadap sesama. Tingkatkan rasa kerjasama kepada siapapun untuk meningkatkan keadilan satu sama lain, tidak saling melempar kesalah satu sama lain. Menjaga keseimbangan antara hakdan kewajiban, menghormati hak orang lain, dan suka memberi pertolongan kepada orang lain agar dapat berdiri sendiri. Yang perlu digaris bawahi adalah jangan menggunakan hak milik untuk usaha-usaha yang bersifat pemerasan terhadap orang lain, hal-hal yang bersifat pemborosan dan gaya hidup mewah, maupun bertentangan dengan atau merugikan kepentingan umum. Banyaknya penggunaan hak milik yang telah dijelaskan membuat banyak timbulnya penipuan dan berperilaku buruk yang merusak bangsa kita. Mulailah dengan hal yang positif seperti bekerja keras, menghargai hasil karya orang lain yang bermanfaat bagi kemajuan dan kesejahteraan bersama, dan melakukan kegiatan dalam rangka mewujudkan kemajuan yang merata dan berkeadilan sosial. Bukan melakukan tindakan yang merusak dan merugikan orang lain.

Pancasila tidak akan bisa membumi jika hanya dijadikan mitos tanpa model praktis dalam memecahkan masalah hidup masyarakat. Oleh karena itu, Pancasila perlu di kembangkan sebagai metodologi hidup atau ideologi praktis. Pada saat ini tidak ada lembaga yang menangani aplikasi Pancasila. Bahkan dalam pendidikan, Pancasila bukan menjadi pelajaran wajib. Apabila Pancasila tidak lagi menjadi perhatian pemerintah maupun masyarakat maka berarti telah sengaja meminggirkan Pancasila sebagai ideologi Negara

\section{SIMPULAN}

Berdasarlam uraian di atas, maka dapat disimpulkan: kompleksnya permasalahan yang dihadapi generasi muda harus dilakukan penguatan nilai-nilai karakter panacsila melalui pendidikan keluarga, sekolah dan masyarakat dengan strategi pembiasaan, keteladanan, penghargaan dan hukuman yang edukatif. 
CIVICS EDUCATION AND SOCIAL SCIENSE JOURNAL(CESSJ)

Volume 1 Nomor 2 Bulan Desember 2019

\section{DAFTAR PUSTAKA}

Agustin, D. (2011). Penurunan Rasa Cinta Budaya Dan Nasionalisme Generasi Muda Akibat Globalisasi. Jurnal Sosial Humaniora.

Albantani, A. M., \& Faizi, A. W. Al. (2015). Pendidikan karakter menuju Indonesia emas 2045. Seminar Nasional Program Studi Pendidikan Guru Madrasah Ibtidaiyah (PGMI).

Abdulkadir Besar. 1994. Pancasila dan Alam Pikiran Integralistik (Kedudukan dan Peranannya dalam Era Globalisasi). Yogyakarta: Panitia Seminar "Globalisasi Kebudayaan dan Ketahanan Ideologi" 16-17 November 1994 di UGM.

Awaludin. dkk. 2006. Pendidikan Kewarganegaraan . Jakarta: Erlangga

Danandjaja, J. (2014). Metode Penelitian Kepustakaan. Antropologi Indonesia. https://doi.org/10.7454/ai.v0i52.3318

Djuliyarsih. dkk. 2006. Pendidikan Kewarganegaraan . Jakarta: Erlangga

Mirzaqon, A., \& Purwoko, B. (2018). Studi Kepustakaan Mengenai Landasan Teori Dan Praktik Konseling Expressive Writing Library. Jurnal BK UNESA.

Muhammad Sulhan. (2018). PENDIDIKAN KARAKTER BERBASIS BUDAYA DALAM MENGHADAPI TANTANGAN GLOBALISASI. Visipena Journal. https://doi.org/10.46244/visipena.v9i1.450

Mustari, M. I., Mohamed, A. K., Jasmi, K. A., \& Ya'akob, R. (2004). Pembentukan Nilai dan Kecemerlangan Bagi Melahirkan Generasi Muda yang Mapan dalam Menghadapi Era Pasca Modenisme. Seminar Antarabangsa Nilai Dalam Komuniti Pasca Modenisme, 2004.

Koento Wibisono. 1988. Pancasila Ideologi Terbuka. Magelang: Panitia Temu Karya Dosen-Dosen PTN Se-Jawa Tengah dan Kopertis Wil.VI.

Kemendiknas RI, Disain Induk Pendidikan Karakter, Jakarta, 2010

Lubis, Maulana Arafat, Pembelajaran PPKn Teori Pengajaran Abad

21 DI SD/MI, Yogyakarta: Samudra Biru, 2018.

Nugroho Triatmojo, Pendidikan Kewarganegaraan, Karakter Bangsa, http://nugi45blog.com, diakses tanggal 06 Mei 2012 
CIVICS EDUCATION AND SOCIAL SCIENSE JOURNAL(CESSJ)

Volume 1 Nomor 2 Bulan Desember 2019

Ningsih, Rini. 2006. Pendidikan Kewarganegaraan. Bogor: Yudhistira

Ningsih, Rini. 2006. Pendidikan Kewarganegaraan . Bogor: Yudhistira

Setiawan, S. (2017). Studi Kepustakaan. Gurupendidikan.Co.Id.

Sumarsono, A. (2018). Pendidikan Karakter Melalui Impelementasi Class Meeting di Sekolah. Seminar Nasional Implementasi Olahraga, Kesehatan Dan Pendidikan Jasmani Terhadap Upaya Peningkatan Karakter Anak Bangsa.

Rukiyati, dkk. Pendidikan Pancasila. Yogyakarta:UNY Press, 2013.

Suparna, Nana. dkk. 2006. Pendidikan Kewarganegaraan . Jakarta: Erlangga

Suparna, Nana. dkk. 2006. Pendidikan Kewarganegaraan untuk SD Kelas VI. Jakarta: Erlangga

Udin Saripudin Winataputra, Jatidiri Pendidikan Kewarganegaraan sebagai wahana Pendidikan Demokrasi, Program Pascasarjana Universitas Pendidikan Indonesia (Disertasi), Bandung,2001

Udin Saripudin Winataputra, Implementasi Kebijakan Nasional Pembangunan Karakter Bangsa MelaluiPendidikan Karakter, PPS Universitas Terbuka, Jakarta, 2010

Yakan, F. (2005). Generasi muda dan perubahan. Pustaka Salam.

Yoga Agustin, D. S. (2011). PENURUNAN RASA CINTA BUDAYA DAN NASIONALISME GENERASI MUDA AKIBAT GLOBALISASI. Jurnal Sosial Humaniora. https://doi.org/10.12962/j24433527.v4i2.632

Zuriah, Nurul. 2007. Pendidikan Moral \& Budi Pekerti Dalam Perspektif Perubahan. Jakarta: PT Bumi Aksara 